\title{
Forms of globalisation: from 'capitalism unleashed' to a global green new deal
}

\author{
Jonathan Michie* \\ Kellogg College, Oxford, UK
}

\begin{abstract}
What is termed 'globalisation' has taken many forms over the centuries. The last time we had a 'free market'form of globalisation, such as is largely in force across the world today, was in the run up to the First World War; goods, people and capital crossed borders, as the leading industrial economies sought economic advantage in a process that ultimately spilled over into armed conflict. This led to a retrenchment between the world wars, with most governments focusing more on their own domestic economies and policy agendas. Following the Second World War, an era of 'managed globalisation' has been dubbed the 'Golden Age of Capitalism'. This was followed by the era, launched by the Thatcher and Reagan administrations, of deregulation, privatisation, financialisation and demutualisation of 'capitalism unleashed'. That led to the 2007-2008 global financial crisis and the 2009 Great Recession. We now need to shape a new historical era, focused on environmental and social sustainability. This will require new economic thinking, and a policy agenda around a global green new deal.
\end{abstract}

Keywords: globalisation, global financial crisis, green new deal

JEL codes: E02, E32, E44, E61, F62

\section{INTRODUCTION}

This article makes three main arguments: First, that the 2007-2008 global financial crisis, and the resulting recession, which was the first on a global scale since the 1930s, was caused by globalisation - not by the 'fact' of globalisation, but rather by its 'form'. Globalisation is not a state in which the world either is or is not: there have been many degrees and forms of globalisation, most forcefully since the rise of capitalism as an economic system, so it is the nature and form of globalisation that is the issue, not whether globalisation as a 'thing' is either present or absent, or good or bad. It was the particular free-market, 'capitalism unleashed' form of globalisation which had been promoted since the 1980s that was the fundamental cause of the 2007-2008 global financial crisis, which ten years later is still weighing heavily on the economy and society across many parts of the globe. ${ }^{1}$

Second, none of this is inevitable. The 'capitalism unleashed' form of globalisation is not determined by technology, nor by any other single factor. It is the outcome of political and other choices made by a range of decision-makers. It was the collective effect of these decisions, and the forces behind them, which created the destructive form of globalisation which has proven to be so costly to society. A different set of decisions, with different priorities, values and objectives could and should be pursued over the coming historical era. This would not abolish or get rid of globalisation; rather, it would change its nature - for the better.

* Email: jonathan.michie@kellogg.ox.ac.uk.

1. 'Capitalism unleashed' was the term coined by Andrew Glyn to describe this phase of deregulated, destructive capitalism: see Glyn (2006). 
And third, amongst the priorities that should shape a new era of sustainable economic development is the need to protect the natural environment - to halt and if possible reverse climate change. In terms of the functioning of the economy, a key goal should be to promote a greater degree of corporate diversity, most especially in the financial services sector, replacing the current domination of 'too big to fail' shareholder-owned companies with a range of smaller, networked companies owned not by external shareholders but by their employees, customers and local communities. Such member-owned organisations tend to have different values and corporate purposes than do shareholder-owned companies, with concomitant differences in behaviours, policies and practices, and different decision-making imperatives. Greater corporate diversity contributes towards increased economic resilience; and replacing the 'greed is good' corporate culture as the dominant driving force in the economy makes less likely the sort of catastrophic consequences wreaked on the world's economic system by the 2007-2008 global financial crisis.

The rest of this paper is structured as follows. In Section 2, the 2007-2008 global financial crisis is discussed, as are the resulting policy responses. In Section 3, attention is paid to the pledge that was made, most especially in the UK, to promote a greater degree of corporate diversity, both to reduce the likelihood of such financial crises being created, and also to increase the economy's degree of resilience when faced with such crises. In Section 4, the need to shift the trajectory of the global economy in a world historic sense, to create a new historical epoch - a global green new deal - is argued. Finally, in Section 5, the conclusion considers how this agenda might best be promoted, including through changing the way people think about economics.

\section{THE 2007-2008 GLOBAL FINANCIAL CRISIS AND THE RESULTING 2009 RECESSION}

The 2007-2008 global financial crisis was caused fundamentally by the deregulatory, freemarket values, policies and practices which constituted the era of 'capitalism unleashed' the 'greed is good' phase of capitalism which had been promoted by the Thatcher and Reagan administrations of the 1980s, and had gained momentum and ideological confidence following the collapse of the Soviet Union. The abolition of exchange controls created a vast market in international financial speculation. At the time it had been argued that this would be a one-off movement, to make up for the inability of such funds to have moved previously - much like the removal of a dam creating a one-off flow of water. However, as so often with free-market economic arguments, the opposite proved to be the case. The speculative flows led to the creation of new markets in financial speculation which in turn drove further speculative flows in a continuing cycle. The politics of the era enabled and sustained increased inequality within most countries. Those at the bottom of the income and wealth distribution turned to the use of growing levels of credit to maintain living standards, and the resulting US 'sub-prime' housing loans were diced and spliced to be added as ingredients for the new 'financial products' being traded in international financial markets. (On the role of inequality in creating credit growth amongst the poor, see for example van Treeck 2015.) Meanwhile, those at the top of the wealth distribution demanded ever greater financial returns on their money, leading in turn to more exotic 'financial products' to deliver historically - and what turned out to be unsustainably - high financial returns. Thus, the demands of the 'high net worth individuals' for greater financial returns fed this speculative frenzy, and played a significant role in the creation of the boom and its subsequent bust (as documented in detail by Lysandrou 2011).

When the resulting global financial crisis of 2007-2008 was threatening to unleash a complete breakdown of the international financial system, a 1930s-style global depression 
was avoided only through the pursuit of an internationally coordinated Keynesian fiscal response, with governments boosting spending across the globe. This was accompanied by huge financial support being provided to the banking sector, including in most countries nationalisation of many shareholder-owned companies. Ultra-low interest rates were accompanied by central banks pursuing the use of 'quantitative easing'. Such measures played a role in stimulating economic activity, which by preventing too great a rise in unemployment will have helped those at the bottom end of the income distribution; but at the same time these policies operated by boosting the price of assets, and hence most likely exacerbated the underlying economic inequality in society - by increasing the value of assets that were held by the already wealthy - which had contributed to the global financial crisis in the first place. (Thus, the counterfactual need not be the absence of policy intervention, but rather the pursuit of a more egalitarian approach.)

In the UK, there were also pledges made for action on banking reform, rebalancing the economy away from finance towards manufacturing, promoting a greater degree of corporate diversity, pursuing industrial strategies ${ }^{2}$ and ensuring regional balance.

\subsection{Return to orthodoxy, and a lost decade}

However, once the threat of a 1930s-style global depression had been avoided - with only particular countries, such as Greece, suffering that fate, rather than the world economy as a whole - the forces that had led to the financial crisis in the first place, having not been removed or even seriously reformed, returned to pursue their previous agendas. Corporate leaders returned to promoting 'shareholder value', fuelling financial rewards for wealth-holders and those holding executive positions. In the face of such behaviour, the reaction of politicians and other policy-makers also reverted to type, acceding to such behaviour if not necessarily condoning it through a failure to pursue any alternative of serious reform.

Thus, the initial Keynesianism - with coordinated fiscal stimuli - gave way to a return to orthodoxy, with governments pursuing 'austerity', involving public spending cuts at national, regional and local levels. This return to orthodoxy undermined and in many cases actually prevented the sort of economic recovery that would have usually followed from such a recession. The reform agenda such as it was following the 2007-2008 global financial crisis never really sought to tackle the underlying causes of the crisis, namely the 'capitalism unleashed' form of globalisation that had been pursued since the 1980s in various forms across the world. This process - launched initially by the Thatcher and Reagan administrations - of deregulation, privatisation, financialisation and demutualisation left nation states more fragile, regions less resilient, and the international system more prone to contagion. These processes and the policy agenda that would be required to move to a more balanced and resilient economy both within and across borders have been analysed by various authors, including those brought together by Michie (2011b). ${ }^{3}$

This failure to have pursued any really serious or appropriate reform agenda leaves the global economy ten years later still prone to further such crises; and ill prepared to deal with any such recurrence. Inequality within countries is as great as ever. Regional imbalances remain. Economies continue to be dominated by shareholder-owned companies, with share buy-back and other such policies being used once again to inflate share prices - and the related executive bonuses. Global financial speculation remains largely unregulated. Tax evasion and avoidance continues internationally on an industrial scale. The illegality of that tax evasion creates strong

2. See http://theconversation.com/how-to-drive-britains-new-industrial-strategy- 80770 .

3. 1st edition 2003; forthcoming (3rd) edition due 2019. 
incentives for such funds to seek returns in markets operating 'below the radar' - through the 'dark web', and illegality generally - the drugs trade, illegal arms trade, and trade in peopletrafficking, for use in the sex industry and for slavery (on which, see Michie 2017b: ch. 9).

\section{THE UK: PROMOTING GREATER CORPORATE DIVERSITY?}

A key component of any serious reform agenda needs to be tackling the dominance of the economy by 'too big to fail' shareholder-owned companies, driven to 'maximise shareholder value', with executive compensation packages often linked to the share price, thus incentivising behaviours that will prioritise this - the short-term inflation of share prices - rather than promoting long-term investment in research and development, in education and skills, and in the productive infrastructure. A different approach is needed, to include the promotion of a range of alternative corporate forms, including public ownership at national, regional and local levels, and also promoting 'member-owned' companies - employee-owned firms, consumer cooperatives, financial mutuals, and so forth. (The need for this is argued in detail by Michie 2011a, and by the various authors brought together by Michie et al. 2017.)

In the UK, the 2010-2015 coalition government (formed by an alliance between the Conservative Party and the Liberal Democrats) pledged to create just such a degree of increased corporate diversity in the financial services sector, including by promoting mutuals (or member-owned financial institutions). ${ }^{4}$ But whilst the government made this pledge to increase the degree of corporate diversity, their lack of resolve might have been suspected from the fact that they failed to introduce any measure of corporate diversity - so there would be no way of telling whether they were succeeding in achieving this policy goal or not. A measure was therefore developed by Professor Christine Oughton and myself, which enables us to track the results of this new activism by government, to create a more resilient economy through fostering a greater degree of corporate diversity (as reported and discussed by Michie/Oughton 2014). The results found that the government's performance in boosting corporate diversity was disappointing, but perhaps in retrospect not surprising: far from the degree of corporate diversity improving, which was so desperately needed and was the clear commitment of government to bring about, it deteriorated (ibid.).

Figure 1, in which a downward movement in the index indicates a deterioration in the degree of corporate diversity, indicates how in the run-up to the financial crisis, things had indeed been getting worse on this score. Full details regarding the conceptualisation and construction of the ' $\mathrm{D}$ index', which factors are included and with what weights, are reported and discussed in Michie/Oughton (2014), but, briefly, it focuses on diversity in corporate ownership (shareholder ownership versus member ownership), but also including the degree of geographical diversity. Following the pledge to put things right, it can be seen that there was little progress - not even a return to the situation which pertained prior to the deterioration in the years leading up to the financial crisis. This is not surprising, as despite the government's pledge, they did little to promote the creation of new financial mutuals. There was no reversal of the disastrous policy of demutualisation, which had from the 1990s transferred the member-owned companies that provided most house-buying finance in the UK into shareholder-owned firms. (These member-owned organisations that were converted into private banks either failed or were bought up by other banks; not a single one survived as an independent company.)

Perhaps the most blatant failure of government to honour its pledge was the case of Northern Rock, which had for generations been a successful member-owned building society, serving

4. As advocated by Michie/Llewellyn (2010). 


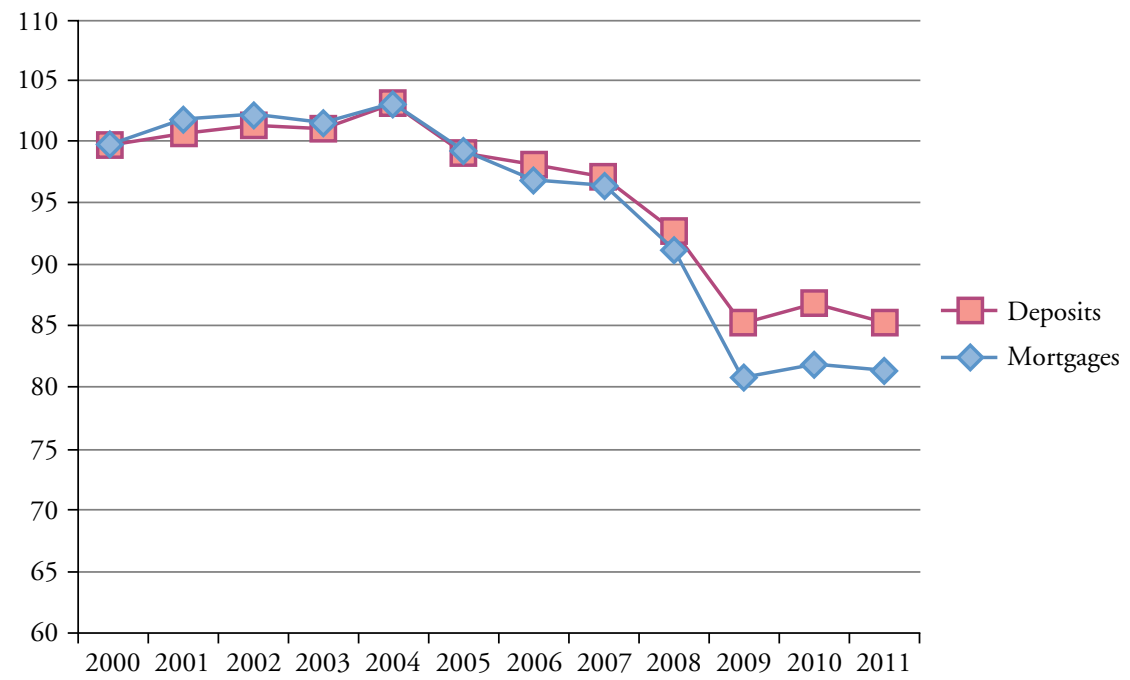

Source: Michie/Oughton (2014).

\section{Figure 1 The 'D index', measuring the diversity of financial services}

both to look after people's savings, and advancing them mortgages for their house purchases, but which had been turned into a private bank as part of the wave of demutualisations. It then gained international fame - or notoriety - by reinventing the bank run, which had been thought to have been a thing of the past, belonging to a bygone era before the financial services sector became regulated and hence trusted. As a - now - private bank it followed the abovedescribed behaviour of chasing ever-higher returns through ever-riskier business practices. The point was thus reached when its customers began to doubt whether they had really retained sufficient funds to repay savings should the customers seek to withdraw them. So, the customers queued up outside the bank to withdraw their funds. And sure enough, the funds proved inadequate. The bank was bankrupted. The bank run was reinvented.

The government had to step in to take the bankrupt bank into public ownership. The obvious subsequent move would have been to return Northern Rock to the mutual sector, as a member-owned company. Oxford's Centre for Mutual \& Employee-owned Business briefed government representatives on how this could be best achieved. Instead, the government sold the company to a combination of Richard Branson and North American hedge funds. When questioned in Parliament why they had not pursued the option of remutualising the company, the responsible Minister claimed they had received no such advice (as reported in Hansard).

One important aspect of corporate diversity - and hence of the diversity index (the ' $D$ index') - is that of regional diversity. The aim should be to have balanced economic development in a geographic sense, rather than having economic growth and prosperity concentrated in only one or a few regions within a country, with other areas stagnating and being left behind. In addition, each individual region needs to be resilient in an economic sense, and this requires a productive economic infrastructure, appropriate levels of education, training and skills, and so forth. There is a large literature on this need for resilient regions - as brought together and discussed for example by Christopherson et al. (2010). 
Table 1 GDP per person of poorest ${ }^{\mathrm{a}}$ and richest ${ }^{\mathrm{b}}$ regions, 2000 vs 2015

\begin{tabular}{lcccc}
\hline & 2000 poor & 2015 poor & 2000 rich & 2015 rich \\
\hline Sweden & 80 & 80 & 140 & 140 \\
Spain & 75 & 80 & 140 & 150 \\
Japan & 70 & 70 & 200 & 190 \\
Italy & 50 & 50 & 180 & 190 \\
S. Korea & 60 & 60 & 220 & 200 \\
France & 50 & 50 & 260 & 300 \\
USA & 70 & 70 & 290 & 320 \\
Germany & 45 & 45 & 310 & 390 \\
Britain & 50 & 50 & 848 & 1150 \\
\hline
\end{tabular}

Notes: National average $=100$.

a. At purchasing power parity, 2010 prices.

b. OECD lower level regions and US states.

Source: The Economist.

As can be seen from Table 1, the degree of regional inequality varies across countries, with Britain being the most unequal. The degree of regional inequality in most countries deteriorated over the 15 years from the year 2000 to 2015, and the worst case of such a deterioration was in Britain.

At the time of the UK's Brexit referendum it was argued that the economy had recovered, and that living standards were by then already higher than they had been prior to the 2007-2008 global financial crisis. Yet the vote to leave the EU was widely seen as a protest vote against economic failure, austerity and a feeling of being 'left behind'. How can these two factors be reconciled, of economic recovery, yet voter disillusionment? The answer lies partly at least in geography and regional imbalances. The recovery in GDP per head turned out to be concentrated in just two regions of the UK: London, and the South East. It was not the case in any other region, and support for Brexit was strongest in those regions left behind. Hence, perhaps, the vote.

\section{A GLOBAL GREEN NEW DEAL}

Tony Blair once declared that: 'Globalisation is changing the nature of the nation state as power becomes more diffuse and borders more porous. Technological change is reducing the capacity of government to control a domestic economy free from external influence' (Blair 1995). At the risk of courting controversy, I would suggest that Tony Blair was mistaken: the current international economic and political arrangements that are generally referred to as constituting globalisation are the result of policy decisions taken by politicians such as Blair, as well as the actions of companies and others, and those decisions can be reversed and other decisions and approaches can and should be taken; governments are in any case not entirely constrained even by the current 'capitalism unleashed' form of globalisation, although certainly a more democratic form of international economic arrangements could and should be brought about. ${ }^{5}$

Thus, the concept of globalisation needs to be seen in its historical context. Capitalism as a system has always sought to make money by operating across borders - trading, and if

5. For a discussion and critique of this speech by Tony Blair, and his associated policy agenda, see for example Cole (1998). 
necessary moving capital, and people. Thus, Sutcliffe/Glyn (2003) argue that although today's economy is by any measure 'globalised', that has not been the result of some natural one-way evolution over time. Quite the contrary, when capitalism as an economic system was first developing, it generated in many ways a similar degree of globalisation, before that process led to the First World War, the Great Depression of the 1930s, and the Second World War. We have perhaps returned to a similar sort of era to the one which preceded the First World War; that may be an unnerving comparison, but there are certainly parallels. One thing is certain: 1989 did not represent the end of history.

Indeed, Chang (2011) argues that the 'principle' of free trade and free-market capitalism internationally - that the developed countries espouse today - is, in effect, hypocritical and cynical, in that those same countries used quite different, interventionist policies to develop their own economies, generally developing behind barriers to trade and free capital movements. Only when their economies had developed, giving them a comparative advantage over others, did those countries advocate the scrapping of such barriers, as they were now in the best position to exploit such free trade, at the expense of others.

The current 'capitalism unleashed' form of globalisation, which included the abolition of exchange controls, in turn leading to a huge increase in global financial speculation, was to blame for creating the 2007-2008 global financial crisis. Famously, it was left to Queen Elizabeth II when visiting the London School of Economics to ask why economists had failed to foresee the crash. The response that was sent to the Queen some weeks later failed to admit that the economics profession had not only failed to foresee the disastrous and hugely costly crash, but had indeed been cheerleaders for the sort of free-market policies that actually created the financial crisis. Those economists who had for years been questioning the mainstream economics consensus, and had been warning against its free-market policy prescriptions, were generally sidelined by the economic orthodoxy, including through appointments and promotions procedures, acceptances (or rather the lack of them) to publish in mainstream journals, and so on.

The crisis, and the questions posed by Queen Elizabeth and others, has however opened up some space for alternative thinking and reform proposals. This is to be welcomed. But there is a long way to go, as the various attempts at reform that have been pursued both nationally and globally have not as yet succeeded in moving the international economy beyond its 'capitalism unleashed' era. What is needed is globalisation for a purpose. And that purpose needs to be above all to promote environmental and social sustainability. The point is not, therefore, to pose nationalism versus globalisation, but, rather, to pursue these goals of sustainability at local, regional, national and global levels, as appropriate. At the heart of this needs to be to ensure that companies have a clear corporate purpose, with concomitantly appropriate corporate ownership models, and corresponding values, policies and practices that promote long-term stewardship and sustainability.

\subsection{The need for environmental sustainability}

The need for environmental sustainability must surely be the most vitally and urgently important issue that faces humanity, because if globalisation were to continue along its current trajectory, the world's future, and the prospects for the survival of the human race itself, may become increasingly uncertain. Current production and trade patterns threaten catastrophic climate change, with unknowable impacts upon oxygen levels in the atmosphere and other such developments which could threaten the very survival of human life on earth. The old ways of organising production and trade need to be abandoned. The environment needs to become central to all decision-making. This means 
abandoning the idea that the 'free market' can solve the problem, whether combined with carbon pricing or not. Whether goods and services should be produced - and if so how, where, and when - are questions that should be decided upon in relation to what the impact would be on climate change. The world is complex, and mainstream economics needs to accept that it does not and cannot have all the answers. We need multidisciplinary and interdisciplinary research. This in turn requires a more open approach from economists, both to other disciplines, and to those from within economics who take an approach different from the mainstream - evolutionary and institutional economists, for example, as well as environmental.

The various authors collected together by Dietz et al. (2011) make this case, on the need for environmental sustainability, and set out the policy framework required across the range of key actors - companies and managers, politicians and practitioners, consumers and producers - and argue that all this needs to be underpinned by a proper understanding of the political economy of the environment. At a corporate level, we need an approach based on the long-term stewardship - rather than the short-term exploitation of assets, and this needs to be pursued at all geographical levels, from the local to the global. On the need for good governance to be pursued at the global level, and the interaction of globalisation on the one hand and democratic processes on the other, see the various authors brought together in Michie (2017a), where I argue that:

There could hardly be a more appropriate time in world history to be revising the issues of globalisation and democracy. After almost two centuries of what might be regarded as globalisation in the current usage of the term, two world wars followed by an era of regulated globalisation, we had thirty years of unregulated globalisation leading up to the 2007-2008 global financial crisis and subsequent 2009 global financial recession, followed by what will soon have been a 'lost decade' of stagnation, austerity, instability, and inequality. The previous consensus, that 'globalisation was the only game in town', promoted by all mainstream political parties, has fallen into disrepute. Voters have used the ballot box to reject both the concept of globalisation and the mainstream parties that promoted it. The UK voted to leave the EU, in the 2016 'Brexit' referendum, and the US elected Donald Trump as President (even though many more voted for Hilary Clinton, and many more still failed to vote for either).

So, where did it all go wrong? Hodgson (2011) argues that the failure of the globalised economy also represented a failure of mainstream economics, which had backed the 'Washington Consensus', and either turned a blind eye or even applauded the 'capitalism unleashed' form of globalisation which wreaked such havoc on the environment, created inequality and instability, and may even cause its own collapse.

Thus, as argued above, we need a change in policy - towards a global green new deal and we also need a new economics: more pluralist, realistic, and open to working with other disciplines. The failed 'capitalism unleashed' form of globalisation needs to be replaced. The Washington Consensus needs to be rejected. We need a global green new deal that will prioritise the future of our planet, seeking to halt the disastrous climate change. And we need a more realistic and open form of economic analysis in order to focus on these real-world issues, and to recognise that we don't just need changes 'at the margin', and in response to 'price signals' - we need major step-change action, with the use of legislation, regulation, public ownership, and the promotion of greater corporate diversity, with cooperative and other member-owned forms of organisation, focusing on local and regional economies. Such an approach could rejuvenate economic analysis, revitalise democratic engagement, and promote an environmentally and socially sustainable future. 


\section{CONCLUSION}

Keynes's (1936) General Theory of Employment, Interest and Money is generally remembered for making the point that effective demand drives economic activity, and that governments can therefore tackle problems of unemployment by boosting effective demand through active fiscal policy. But it is worth recalling that what drove Keynes to write the book was not simply to make that technical point, but, rather, to change the way that people thought about economics. We face a similar need today - to change the way people think about the economy and economics. In part, this is to continue the task that Keynes himself was undertaking, as his attempt at overthrowing the old 'Treasury' view has still not been fully achieved. Indeed, the economic policies of austerity that have been pursued by governments over the past few years rely heavily on exactly those pre-Keynesian 'Treasury' views that Keynes had sought to overcome.

We also need a more open, interdisciplinary approach to analysing and tackling the great issues of our time. In the case of climate change it should be self-evident that we need climate change scientists along with social scientists who understand issues of consumer behaviour and behavioural change, management decision-making, and so forth. Here I should declare an interest, as I have long argued that interdisciplinary research needs to be promoted, incentivised and rewarded, including through the 'Research Assessment Exercises' and now the 'Research Excellence Framework' (REF) - through which the quality of university research is measured in the UK, on the basis of which decisions are made on funding allocations to universities - and it is greatly to be welcomed that at last there is to be a serious attempt to make this so in the next such exercise, REF2021, with the appointment to the REF assessment panels of members with an explicit remit of advising specifically on the interdisciplinary aspects of research (and I am pleased to have been appointed to such a role for the 'Management and Business' panel). It is to be hoped that this development will encourage a more realistic approach to economic analysis and policy-making, with proper account taken of institutional and behavioural factors, and of the complexity of economic processes. ${ }^{6}$

This need for both a new economic policy agenda and a new way of approaching economics has been argued for by a range of authors. The organisation 'Promoting Economic Pluralism' seeks to encourage dialogue across the various schools of thought within economics. ${ }^{7}$ Thus, for example, Kate Raworth (2017) argues that we need a new set of rules and insights to guide the global economy and to help tackle the great challenges we face, from climate change and inequality to financial instability. Such an agenda is also promoted actively by the Forum of Macroeconomics and Macroeconomic Policies, including through their annual conferences, and by the European Journal of Economics and Economic Policies, and others such as the Cambridge Journal of Economics and the International Review of Applied Economics. Alongside this has been the pressure from students for a more appropriate and realistic approach to the teaching of economics - a call being responded to in many universities across the globe, including through the online courses provided by my own department at Oxford. ${ }^{8}$

The Great Depression of the 1930s led to Keynes's 1936 attempt to change the way that people thought about economic policy. This in turn led on to an era of economic

6. On the role of complexity in economic processes, and hence the importance of complexity theory for economics as a discipline, see Foxon et al. (2013).

7. In the interests of full disclosure, I should declare that I am a founding Trustee of the organisation 'Promoting Economic Pluralism'.

8. See www.conted.ox.ac.uk - for example, http://www.conted.ox.ac.uk/globalisation-online? code $=\mathrm{O} 17 \mathrm{P} 512 \mathrm{SOV}$. 
development referred to now as the Golden Age of Capitalism, from 1945 through to the early 1970s. We now need to replace the era of 'capitalism unleashed', which spread across the globe from the 1980s - and which caused the first global recession since the 1930s, in 2009 following the 2007-2008 global financial crisis. This will require a more realistic approach to analysing the workings of the economy; a policy agenda to promote new corporate forms and greater corporate diversity, greater regional resilience and reduced inequality; and above all the tackling of climate change, to deliver environmental and social sustainability.

\section{ACKNOWLEDGEMENT}

An earlier version of this paper was presented at the 21 st Conference for the Forum of Macroeconomics and Macroeconomic Policies, held in Berlin in November 2017; I am grateful for interesting and helpful questions and comments received from several of the conference participants, and in particular to the organising committee, who are also the guest editors of this volume.

\section{REFERENCES}

Blair, T. (1995): Speech at NewsCorp Leadership Conference, Hayman Island, Australia, 17 July.

Chang, H.-J. (2011): Kicking away the ladder - globalisation and economic development in historical perspective, in: Michie, J. (ed.), The Handbook of Globalisation, 2nd edn, Cheltenham, UK and Northampton, MA: Edward Elgar Publishing, 465-474.

Christopherson, C., Michie, J., Tyler, P. (2010): Regional resilience: theoretical and empirical perspectives, in: Cambridge Journal of Regions, Economy and Society, 3, 3-10.

Cole, M. (1998): Globalisation, modernisation and competitiveness: a critique of the new labour project in education, in: International Studies in Sociology of Education, 8(3), 315-333.

Dietz, S., Michie, J., Oughton, C. (eds) (2011): The Political Economy of the Environment: An Interdisciplinary Approach, London: Routledge.

Foxon, T.J., Köhler, J., Michie, J., Oughton, C. (2013): Towards a new complexity economics for sustainability, in: Cambridge Journal of Economics, 37(1), 187-208.

Glyn, A. (2006): Capitalism Unleashed: Finance, Globalization, and Welfare, Oxford: Oxford University Press.

Hodgson, G.M. (2011): The great crash of 2008 and the reform of economics, in: Michie, J. (ed.), The Handbook of Globalisation, 2nd edn, Cheltenham, UK and Northampton, MA: Edward Elgar Publishing, 518-537.

Keynes, J.M. (1936): The General Theory of Employment, Interest and Money, London: Macmillan.

Lysandrou, P. (2011): Global inequality and the global financial crisis: the new transmission mechanism, in: Michie, J. (ed.), The Handbook of Globalisation, 2nd edn, Cheltenham, UK and Northampton, MA: Edward Elgar Publishing, 495-517.

Michie, J., Llewellyn, D.T. (2010): Converting failed financial institutions into mutual organisations, in: Journal of Social Entrepreneurship, 1(1), 146-170.

Michie, J. (2011a): Promoting corporate diversity in the financial services sector, in: Policy Studies, 32(4), 309-323.

Michie, J. (ed.) (2011b): The Handbook of Globalisation, 2nd edn, Cheltenham, UK and Northampton, MA: Edward Elgar Publishing. (3rd edn forthcoming, 2019.)

Michie, J. (ed.) (2017a): Globalisation and Democracy, three volumes, Cheltenham, UK and Northampton, MA: Edward Elgar Publishing.

Michie, J. (2017b): An Advanced Introduction to Globalisation, Cheltenham, UK and Northampton, MA: Edward Elgar Publishing. 
Michie, J., Oughton, C. (2014): Measuring diversity in financial services markets: a diversity index, Working Paper 097_DP113, Centre for Financial and Management Studies, SOAS, University of London.

Michie, J., Blasi, J., Borzaga, C. (eds) (2017): The Oxford Handbook of Mutual, Co-operative, and Co-owned Business, Oxford: Oxford University Press.

Raworth, K. (2017): Doughnut Economics: Seven Ways to Think Like a 21st Century Economist, White River Junction, VT: Chelsea Green Publishing.

Sutcliffe, B., Glyn, A. (2003): Measures of globalisation and their misinterpretation, in: Michie, J. (ed.), The Handbook of Globalisation, 1st edn, Cheltenham, UK and Northampton, MA: Edward Elgar Publishing, 61-78. (2nd edn 2011).

Treeck, T. van (2015): Inequality, the crisis, and stagnation, in: European Journal of Economics and Economic Policies: Intervention, 12(2), 158-169. 